\title{
Life cycle assessment of point source emissions and infrastructure impacts of four types of urban stormwater systems
}

Brudler, Sarah; Arnbjerg-Nielsen, Karsten; Hauschild, Michael Zwicky; Ammitsøe, Christian; Hénonin, Justine; Rygaard, Martin

Published in:

Water Research

Link to article, DOI:

10.1016/j.watres.2019.03.044

Publication date:

2019

Document Version

Peer reviewed version

Link back to DTU Orbit

Citation (APA):

Brudler, S., Arnbjerg-Nielsen, K., Hauschild, M. Z., Ammitsøe, C., Hénonin, J., \& Rygaard, M. (2019). Life cycle assessment of point source emissions and infrastructure impacts of four types of urban stormwater systems. Water Research, 156, 383-394. https://doi.org/10.1016/j.watres.2019.03.044

\section{General rights}

Copyright and moral rights for the publications made accessible in the public portal are retained by the authors and/or other copyright owners and it is a condition of accessing publications that users recognise and abide by the legal requirements associated with these rights.

- Users may download and print one copy of any publication from the public portal for the purpose of private study or research.

- You may not further distribute the material or use it for any profit-making activity or commercial gain

- You may freely distribute the URL identifying the publication in the public portal 


\section{Accepted Manuscript}

Life cycle assessment of point source emissions and infrastructure impacts of four types of urban stormwater systems

Sarah Brudler, Karsten Arnbjerg-Nielsen, Michael Zwicky Hauschild, Christian Ammitsøe, Justine Hénonin, Martin Rygaard

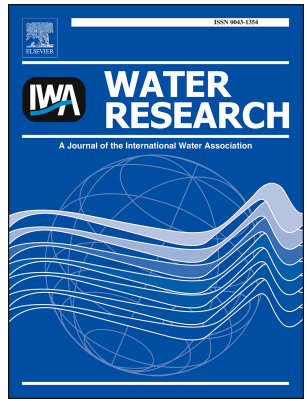

PII:

S0043-1354(19)30266-0

DOI: https://doi.org/10.1016/j.watres.2019.03.044

Reference: WR 14531

To appear in: Water Research

Received Date: 2 October 2018

Revised Date: 20 March 2019

Accepted Date: 21 March 2019

Please cite this article as: Brudler, S., Arnbjerg-Nielsen, K., Hauschild, M.Z., Ammitsøe, C., Hénonin, J., Rygaard, M., Life cycle assessment of point source emissions and infrastructure impacts of four types of urban stormwater systems, Water Research (2019), doi: https://doi.org/10.1016/j.watres.2019.03.044.

This is a PDF file of an unedited manuscript that has been accepted for publication. As a service to our customers we are providing this early version of the manuscript. The manuscript will undergo copyediting, typesetting, and review of the resulting proof before it is published in its final form. Please note that during the production process errors may be discovered which could affect the content, and all legal disclaimers that apply to the journal pertain. 


\section{Life cycle assessment of point source emissions and infrastructure impacts of four types of urban stormwater systems}

1 Sarah Brudler ${ }^{a, b}$, *, Karsten Arnbjerg-Nielsen ${ }^{a}$, Michael Zwicky Hauschild ${ }^{c}$, Christian

2 Ammitsøe $^{b, d}$, Justine Hénonin ${ }^{b}$, Martin Rygaard $^{a}$

3 a Urban Water Systems, Department of Environmental Engineering, Technical University

4 of Denmark, Bygningstorvet, Building 115, 2800 Kgs. Lyngby, Denmark

$5 \quad{ }^{b}$ VCS Denmark, Vandværksvej 7, 5000 Odense C, Denmark

$6{ }^{c}$ Quantitative Sustainability Assessment, Department of Management Engineering,

7 Technical University of Denmark, Produktionstorvet, Building 424, 2800 Kgs. Lyngby,

8 Denmark

$9{ }^{d}$ HOFOR, Ørestads Boulevard 35, 2300 København S, Denmark

10 *Corresponding author: sabr@env.dtu.dk

12 Key words: urban water systems, green infrastructure, stormwater discharges,

13 environmental impacts, ecosystem damage, resource availability 


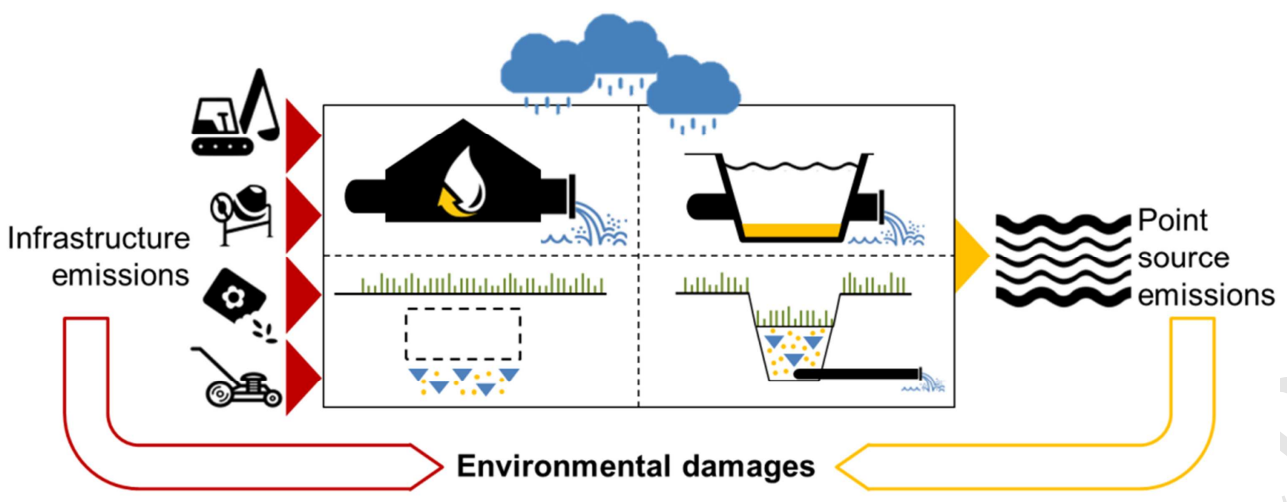

\section{Abstract}

The implementation, operation and decommissioning of stormwater management systems causes environmental damage, while at the same time reducing pollutant loads in receiving waters by treating stormwater. The focus in research has been either on assessing impacts caused by stormwater infrastructure, or risks associated with

21 stormwater discharges, but rarely have these two sources of environmental impacts been combined to allow a comprehensive environmental evaluation of stormwater management.

23 We assess the environmental sustainability of four different generic stormwater

24 management systems for a catchment of 260 ha by a) modelling the flow of pollutants in stormwater, and resulting point source emissions to freshwater, and b) quantifying emissions and resources for all relevant processes associated with the life cycle of the

27 infrastructure. Using life cycle impact assessment, we quantify the resulting environmental

28 impacts and consequent damage to two areas of protection - ecosystems (expressed in 29 time-integrated species loss) and natural resource availability (expressed in extra costs for 30 future resource extraction). Our assessment shows that combined stormwater 
31 management causes the highest damage to both ecosystems (1.4E-03 species.yr/yr) and resource availability $(8.8 \mathrm{E}+03 \mathrm{USD} / \mathrm{yr})$. Separate systems using only green infrastructure were found to avoid damage to resource availability ( -3.7 to $-5.2 \mathrm{USD} / \mathrm{yr})$ and cause lower ecosystem damage (1.1 to $1.3 \mathrm{E}-03$ species.yr/yr). Stormwater discharges contribute significantly to the total ecosystem damage of the different systems (36 to $88 \%$ ), and the sustainability of separate systems can be further improved by optimizing the removal efficiency of low-tech elements like surface basins and filter soil. The systems are designed according to engineering standards. Choosing different criteria, e.g. identical flood safety levels, would result in substantial changes of the relative performance of the systems. The findings highlight the importance of including point source emissions into the assessment to allow comparative conclusions and minimisation of environmental damage of stormwater management.

\section{Introduction}

44 Stormwater management (SWM) aims to prevent damage to humans, property and the 45 environment by limiting exposure to polluted stormwater and preventing flooding. At the same time, the implementation, operation, and decommissioning of these systems cause

47 environmental damage, e.g. through emissions of greenhouse gases associated with the 48 energy and transport that is involved. In this paper, we use life cycle assessment (LCA) to 49 quantify the caused environmental damage (ISO, 2006a, 2006b). The whole life cycle from 50 implementation (material generation, transport and construction), through operation and 51 maintenance, to end of life (decommissioning and disposal or recycling) is considered. As 52 a novelty, we include damage from discharges of polluted stormwater in the assessment. 
LCA is increasingly used to analyse multifunctional systems, such as urban water

54 systems (UWS) (Loubet et al., 2014). Numerous studies assessed the impacts of single installations and some also considered complete SWM systems (Brudler et al., 2016). However, most publications focused on environmental impacts caused by the systems, and did not include impacts from discharges of stormwater itself. This limitation in scope consequently hinders the comparability as these discharges are specific for each SWM system and neglecting differences in their impacts might lead to wrong conclusions. Taylor and Barrett (2008) took pollutant discharges to the environment into account indirectly by

61 relating life cycle impacts of different alternatives to their removal efficiency. Spatari et al.

62 (2011) assessed the changes in electricity consumption at the wastewater treatment plant 63 (WWTP) caused by alternate discharge paths, but neglected impacts by direct discharges.

64 Clauson-Kaas et al. (2001) included eutrophication and toxicity impacts of selected 65 pollutants, but only assessed combined sewer overflow treatment and not a comprehensive strategy including a number of elements to manage stormwater. Byrne et

67 al. (2017) used a similar approach for roadway drainage systems. Wang et al. (2013) 68 included eutrophication impacts of stormwater discharges in the LCA of catchment-wide 69 SWM strategies, but neglected ecotoxicity impacts.

Many compounds are present in stormwater, including nutrients and toxic 71 substances such as metals (Brudler et al., 2019; Ingvertsen et al., 2011). Assessing their 72 impacts using LCA is challenging, as stormwater discharges are characterized by large 73 temporal and spatial variations, which are difficult to represent in LCA which quantifies 74 total emissions but not the resulting environmental concentrations or location specific 75 impacts (Pfister and Hellweg, 2009). Existing publications on pollutants in stormwater have 76 a strong focus on peak concentrations and associated risks (Göbel et al., 2007; Gosset et 
al., 2017; Wicke et al., 2015). In contrast, LCA quantifies long-term, accumulative effects,

78 for which average concentrations are needed. Only recently has life cycle impact assessment been used to quantify impacts of stormwater discharges. Brudler et al. (2019) calculated generic impacts of stormwater discharges, and Risch et al. (2018) assessed the

81 impacts of wet and dry weather discharges. The relative importance of stormwater 82 discharges for the ecotoxicity and eutrophication impacts of SWM systems has never been 83 quantified at catchment scale. Excluding stormwater discharges does not only influence 84 the magnitude of the total impacts, but could also lead to incorrect decisions when comparing different SWM systems with different treatment efficiencies.

To distinguish impacts resulting from stormwater discharges from the impacts

87 associated with the life cycle of the SWM infrastructure, we denote them as point source 88 emission impacts (United States Federal Law, 2002). All other impacts resulting from 89 implementation, operation, and decommissioning of SWM systems are denoted as 90 infrastructure impacts. The two impact sources should be analysed in combination when 91 assessing the environmental sustainability of SWM systems. For example, a reduction of 92 point source emission impacts may be accompanied by increased infrastructure impacts if 93 it is achieved through more extensive treatment. This trade-off has been highlighted also in 94 other areas, e.g. remediation of contaminated sites (Lemming et al., 2010). As a novelty, 95 we quantify all relevant infrastructure and point source emission impacts of four complete 96 SWM systems in a generic case study. We then combine the two to calculate the total 97 environmental damage to assess the environmental performance for the different SWM 98 systems (Figure 1). This allows us to compare the environmental performance of different 99 archetypal SWM systems and to evaluate the relative importance of point source 
100 emissions and infrastructure life cycle. Furthermore, we analyse the uncertainties 101 accompanying the calculated environmental damage.

102

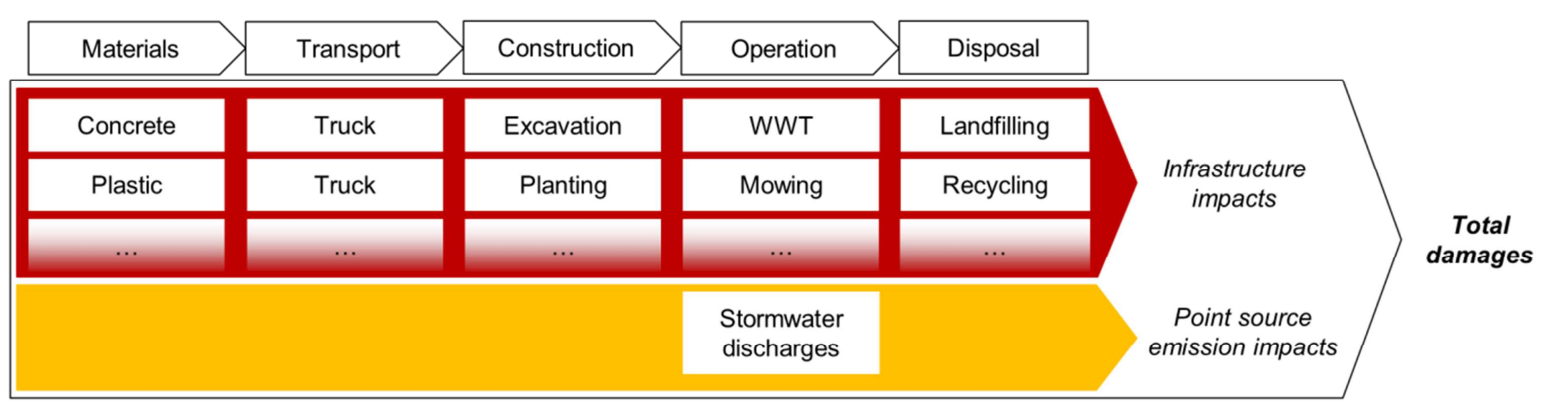

Figure 1. Sources of environmental impacts in stormwater management: infrastructure and point source emission impacts, causing damage.

\section{Methods and data}

When comparing different systems, it has to be ensured that all alternatives fulfil the same essential, primary function, which is expressed in a functional unit (ISO, 2006b). In our case, we defined the functional unit as stormwater management according to existing Danish flood safety standards (IDA Spildevandskomiteen, 2005) in a catchment area of 260 ha (100ha impervious area) over 25 years. The standards dictate that separate systems are to be dimensioned to prevent flooding for events with a return period of five years, while combined systems are to be dimensioned for ten year return periods. This is within the typically accepted range of standards for sewer systems in Europe. The difference in protection level is due to the higher human health risk during flooding with combined sewage. Hence this functional unit is preferred over one of identical flood safety. The standards do not define water quality targets for discharge of stormwater. The catchment characteristics, and infrastructure elements and pollution management in the different systems are further explained in section 2.3. 
The processes required within each of the systems to provide the defined functional unit were described using documentation of existing and planned SWM systems, literature, and expert interviews (SI). Their exchanges with the environment were modelled in EASETECH V2.4.5 (Clavreul et al., 2014) using standard unit process data from the 124 Ecoinvent database (Weidema et al., 2013), and compiled in the life cycle inventory (ISO, 125 2006b).

We considered point source emissions of pollutants in stormwater during the operation stage separately. We first assessed the flow path of stormwater through the different systems, and then quantified the pollutant loads using generic concentration data per litre of stormwater, derived from Brudler et al. (2019). Besides phosphorous (3.2mg/l), only copper $(59 \mu \mathrm{g} / \mathrm{l})$ and zinc $(490 \mu \mathrm{g} / \mathrm{l})$ emissions were included in the point source 131 emission inventory, as they have been shown to cause over $90 \%$ of the ecotoxicity 132 impacts of stormwater discharges across a wide variety of stormwater compositions 133 (Brudler et al., 2019). Removal efficiencies were calculated based on values found in 134 literature and databases for the single SWM elements, and the flow of pollutants was 135 modelled accordingly. Leaching of metals from agricultural soil was modelled using fate 136 factors from the USEtox® model (Rosenbaum et al., 2011). For phosphorous, a 137 conservative leaching rate of $50 \%$ was assumed based on runoff and infiltration factors for 138 different soil types published by Kirkeby et al. (2013).

\subsection{Impact assessment}

In the life cycle impact assessment (LCIA), the life cycle inventory was translated to 
142 calculated as the sum the single substance emissions or resource consumption $E$, 143 multiplied with a midpoint characterisation factor $\left(C F_{m, i}\right)$ that for each flow represents its 144 ability to contribute to the modelled impact:

$$
I_{i}=\sum\left(E * C F_{m, i}\right)
$$

We used the characterisation factors from ReCiPe 2016 for 10 impact categories 147 (Huijbregts et al., 2016). Point source emissions of phosphorous were translated to 148 freshwater eutrophication impacts employing the methodology described by Brudler et al. 149 (2019). To assess toxicity impacts of infrastructure and point source emissions, we used 150 characterisation factors from the USEtox® model (Rosenbaum et al., 2008). USEtox is not 151 part of the ReCiPe 2016 method, but it has the same scope as the method applied in $152 \mathrm{ReCiPe}$ (USES-LCA 2.0), and the substitution leads to no overlapping or double counting 153 with the other impact categories covered by ReCiPe 2016. As impacts on groundwater are 154 not represented in standard LCIA (Lemming et al., 2010), we used characterisation factors 155 for freshwater discharges for leachate reaching groundwater to represent its ecotoxicity 156 impacts. Assuming that all pollutants in the aquifer eventually seep into surface freshwater 157 is a worst case assumption.

Annual point source emissions were calculated directly based on the discharge of 159 pollutants over one year. Infrastructure impacts were first calculated for the whole 160 assessment period of 25 years, and then normalized in relation to the lifetime of the single 161 elements. Annual operation impacts were found as the average annual impacts over the 162 assessment period of 25 years. Total annual impacts $l_{\text {infrastructure,annual, }, k \text { of }}$ system $k$ in the 163 impact category $i$ were then calculated by adding up impacts from all elements: 
$164 I_{\text {infrastructure, annual, }, i, k}=\sum_{j}\left(\frac{I_{\text {material }, i, j}+I_{\text {transport }, i, j}+I_{\text {construction }, i, j}+I_{\text {disposal }, i, j}}{\text { lifetime }_{j}}+\frac{I_{\text {operation }, i, j}}{\text { assessment period }}\right)(2)$

Where $l_{i, j}$ are the total impacts over the assessment period of 25 years, and lifetime $e_{j}$

166 is the expected life span of the element $j$.

Impacts at midpoint level allow to compare systems within specific categories, e.g.

168 to evaluate which scenario has the lowest global warming impacts. To assess the relative 169 performance of the systems at midpoint level, an internal normalisation was performed 170 relating the impacts to the systems with the highest and lowest impact in each impact 171 category by assigning each impact a value between 1 (highest impact) and 0 (lowest 172 impact):

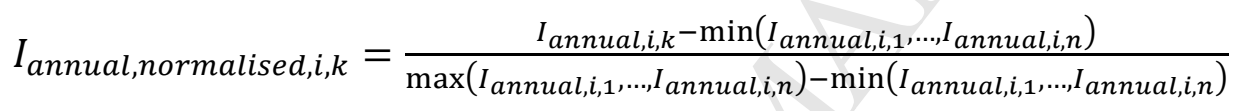

Where $I_{\text {annual,normalised, } i, k}$ is the annual normalised impact of system $k$ in the impact category $i, l_{a n n u a l, i, k}$ is the annual impact of system $k$ in the impact category $i$, and $n$ is the number of compared systems.

At midpoint level, point source emission impacts were assessed separately from the 178 infrastructure impacts to keep track of where environmental impacts arise and analyse 179 how this varies between the compared systems. The separate assessment at midpoint 180 level also allows decision makers to assign different importance to them reflecting their 181 different nature in that the point source impacts occur locally during rain events while the 182 infrastructure impacts are spread over its life cycle and occur at multiple locations.

The scores for the midpoint impact categories are expressed in category specific 184 units, which means that the systems cannot be compared across impact categories. To 
185 allow such a comparison, the resulting environmental damage was calculated for the 186 midpoint scores, reflecting the ability of the midpoint indicators to contribute to damaging 187 different areas of protection that represent components of the environment of direct value 188 to human society (UNEP/SETAC, 2005). In ReCiPe, the areas of protection are defined as 189 ecosystems, resource availability, and human health (Goedkoop et al., 2013). Damage 190 from different impact categories to the same area of protection are expressed in the same 191 unit, which means that the systems' performance can be compared across midpoint 192 impact categories within each area of protection. A midpoint impact category contributes to 193 damage to one or more areas of protection, for example climate change causes damage 194 to ecosystems and human health, but does not affect resource scarcity in the ReCiPe 195 methodology (Huijbregts et al., 2016). We multiplied midpoint impacts with endpoint 196 characterisation factors $C F_{e}$ from ReCiPe 2016 and the USEtox® model, and then added 197 infrastructure and point source emission damage up to calculate total annual damage $198 D_{\text {total,annual }}$ to each area of protection $p$ :

$$
D_{\text {total,annual, }, k}=\sum_{i}\left(I_{\text {infrastructure,annual, } i, k} * C F_{e}\right)+\sum_{i}\left(I_{\text {point source, annual, }, i, k} * C F_{e}\right)
$$

Where $I_{a n n u a l, i, k}$ is the annual impact of system $k$ in the impact category $i$.

\subsection{Case description and systems}

The Skibhus catchment in Odense, Denmark was used as the basis for a generic case study (Zhou et al., 2012). It has an extent of 260ha, of which 100ha are impermeable, and 204 approximately 3,400 buildings and 6,000 inhabitants. The catchment characteristics are typical in a European context: The area is mainly residential, with little industry. It consists of low density housing and green areas, which are used as gardens, parks and allotment gardens. These area characteristics were used to develop four different SWM systems, 
each dimensioned based on full hydrodynamic modelling (MIKE URBAN, DHI) or 209 simplified modelling (WEST, DHI) of such systems. All elements were designed according 210 to existing guidelines and recommendations (CIRIA, 2015; The City of Copenhagen, 2011) 211 (Figure 2).

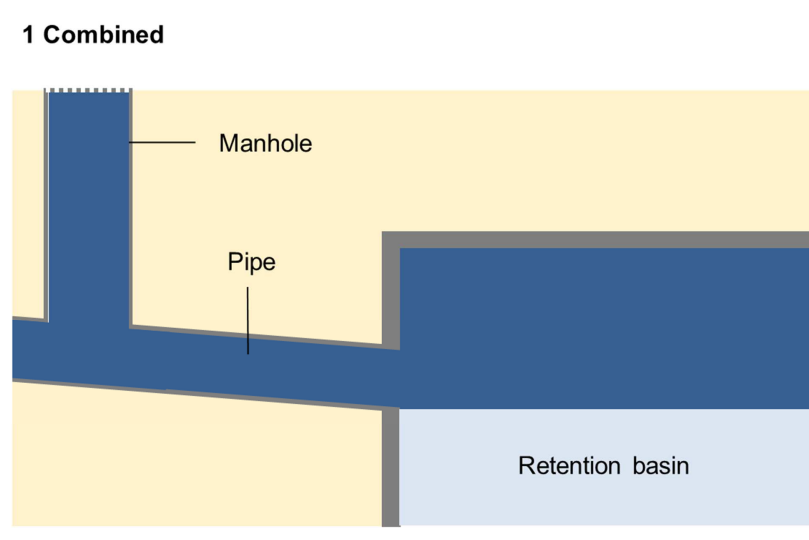

3 Soakaways

a. Private properties

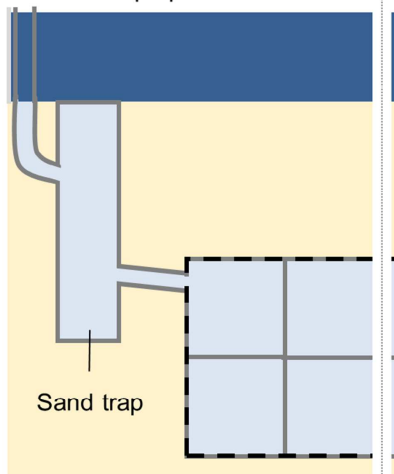

b. Roads

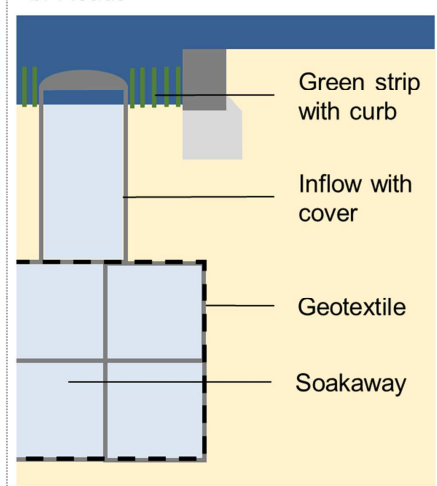

2 Separate

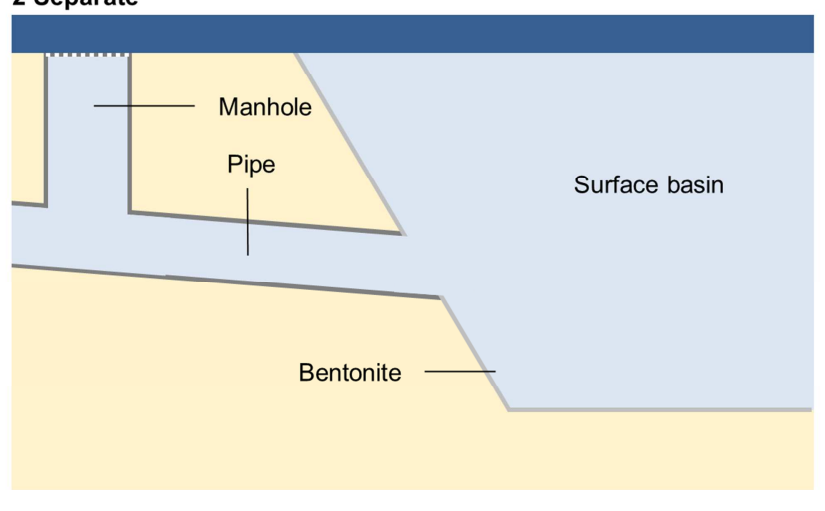

4 Swales

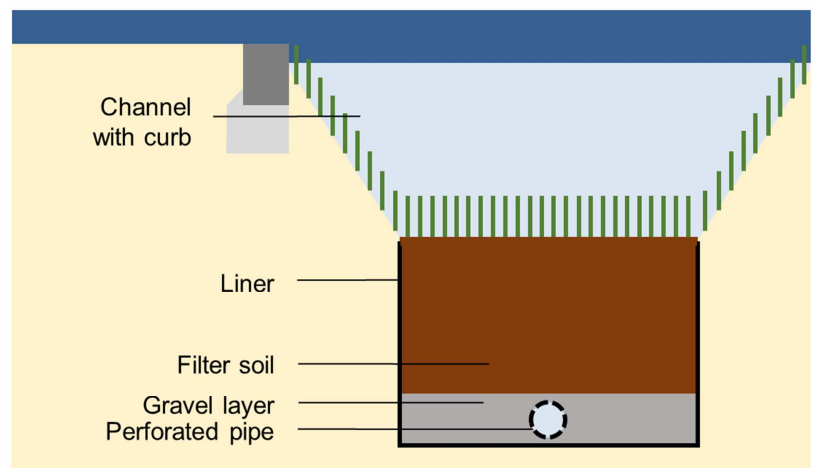

Figure 2. Schematic sketches of the elements in the four different stormwater management systems. The level rises above surface level for events with a return period of 10 years in the systems 2-4.

218 ranging between $200 \mathrm{~mm}$ and $3000 \mathrm{~mm}$. The system was dimensioned to prevent 219 surcharging for events with a return period of up to 10 years. A subsurface retention basin

\section{S1: Combined subsurface system}

Stormwater and wastewater are handled in one pipe system with pipe diameters for mixed sewage was designed to limit combined sewer overflows to the recipient to five 
221 times per year (Nature Agency DK, 2011), which results in a basin volume of $7000 \mathrm{~m}^{3}$.

222 Except for overflows, all combined sewage is treated in a central WWTP. No separate WW 223 system has to be implemented, which was factored in as avoided material demands for 224 WW pipes.

225 S2: Separate subsurface system

226 Stormwater is handled separately from wastewater, in pipes dimensioned to prevent 227 surcharging for events with a 5 year return period $(\varnothing=200-2000 \mathrm{~mm})$. A surface retention 228 basin was dimensioned according to an existing design criterion $\left(200 \mathrm{~m}^{3}\right.$ per reduced ha), 229 which results in a basin volume of $20,000 \mathrm{~m}^{3}$. This criterion is based on water quality 230 considerations, allowing sedimentation and subsequent pollutant removal before discharge 231 (Vollertsen et al., 2012).

S3: Separate system with soakaways

Stormwater is managed completely in soakaways (also called dry wells) 234 dimensioned for a 5-year-event, which results in a total soakaway volume of $26,700 \mathrm{~m}^{3}$. 235 The system is decentralized, i.e. the soakaways are implemented on private properties 236 and existing roads, and not connected. Sand traps for roof runoff and green strips for road 237 runoff partly remove sediments and pollutants. All stormwater is infiltrated from the 238 soakaways. Avoided impacts were quantified for existing road areas that were transformed 239 to green areas, consequently reducing asphalt demands.

\section{S4: Separate system with dry swales}

241 Stormwater is handled in dry swales with a total volume of $20,600 \mathrm{~m}^{3}$, which is 242 provided mainly above the surface. The swales are implemented on existing road areas, 
243 and avoided impacts from avoided asphalt demands were accounted for. The surface area

244 is vegetated for additional pollutant removal. Stormwater percolates through filter soil and 245 gravel before entering a perforated pipe $(\varnothing=80 \mathrm{~mm})$. Infiltration is prevented by a 246 geotextile liner.

\subsection{Assumptions and uncertainties}

248 To make the case study as generic as possible, four simplifications were made:

249 - The existing SWM system was neglected, and it was assumed that a system would be 250 built from scratch;

251 - Stormwater is managed in only one type of SWM element (soakaways or swales) in the 252 green infrastructure systems, instead of a more realistic combination of different 253 elements typically employed in retrofitting;

254 - It was assumed that elements on existing roads would be implemented when road 255 renewals are required, or would only move renewals up in time, i.e. that renewal 256 demands do not differ between the systems;

257 - We assumed that stormwater and WWTP effluent are both discharged to freshwater, 258 which made a worst-case scenario. In reality, the Skibhus catchment is atypical and 259 discharges its stormwater to the harbour, and WWTP effluent to freshwater.

260 The freshwater bodies that the stormwater is discharged to are assumed not to be 261 used for drinking water. If receiving water bodies are used for recreational activities, 262 dilution and the short exposure span is expected to limit harmful effects. Consequently, the 263 exposure of humans to pollutants is considered to be negligible and point source emission 264 damage to human health are therefore not considered. Additionally, human health damage 
265 from stormwater is expected to mainly be caused by pathogens, which is not included in 266 existing LCIA methods.

Electricity consumption has been found to cause the major share of environmental 268 impacts of wastewater treatment (Godskesen et al., 2013), and we therefore did not 269 include other processes at the WWTP. The electricity demand differs depending on the 270 quantity and quality of the influent. Since we were only interested in the incremental 271 change caused by the treatment of stormwater, we analysed electricity consumption at the 272 existing wastewater treatment plant in the catchment for the year 2016 and estimated an average extra electricity consumption of $0.07 \mathrm{kWh}$ per $\mathrm{m}^{3}$ of stormwater (SI).

Impacts from sanitary wastewater management were only considered when they differed between the systems. We assumed that wastewater is treated in a central WWTP in both combined and separate systems, and therefore did not consider point source 277 emissions of treated wastewater. This is a simplification, as the treatment efficiency and 278 consequently the effluent pollutant concentration depends on the influent concentration. 279 Mixing wastewater with stormwater will lead to lower removal efficiencies, which results in 280 different impacts from treated stormwater in combined and separate system. We did not 281 have sufficient data to quantify this effect. However, we included point source emission 282 impacts caused by discharges of untreated wastewater in the combined system (S1). 283 Using data from the year 2016, we calculated an annual combined sewer overflow volume 284 of $4414 \mathrm{~m}^{3}$, of which $3 \%$ is wastewater.

Nitrogen present in stormwater may cause marine eutrophication impacts when 286 discharged to marine water. ReCiPe 2016 does not define characterisation factors for 287 marine eutrophication at mid- or endpoint level (Huijbregts et al., 2016), and these impacts 
288 are therefore not included. However, long-term damage is not expected from nitrogen 289 discharges due to mixing and dilution effects in the sea.

\subsubsection{Uncertainty analysis}

291 To evaluate the uncertainty of infrastructure and point source emission damage, we 292 identified processes contributing significantly to total damage, and varied the input 293 parameters $(\mathrm{SI})$. Uncertainties in infrastructure processes were classified according to 294 Huijbregts (1998) into parameter uncertainty, which includes the filter strip areas for 295 soakaways and the lifetime of green infrastructure elements (soakaways, filter strips, 296 swales), and uncertainty due to choices including the electricity demand and production 297 mix for WWT and for pumping, and the disposal process for plastic. We did not assess 298 model uncertainty, i.e. the uncertainty connected to characterisation factors and impact 299 pathways defined in the underlying LCIA methods. Since we use the same methodology 300 for all systems, we can assume that relative conclusions are valid since the same 301 uncertainty is attached to all results. However, we note that the characterisation at 302 endpoint damage level requires modelling of the full impact pathway and hence has a 303 higher model and parameter uncertainty than the characterisation at midpoint level, 304 particularly for climate change impacts.

305 The point source emissions are determined by the removal efficiency of the single 306 elements in the systems. While pollutant removal in WWTPs is well documented and 307 regulated (Danish Nature Agency, 2014), large variations in the efficiency of low-tech 308 elements like retention ponds and filter soil are documented in literature (Center for 309 Watershed Protection, 2007). Additionally to calculating median removal efficiencies, 310 maximum and minimum removal efficiencies were used to calculate the impacts from all 
311 separate systems (S2-4) in analysis of the sensitivity of the results to this parameter.

312 Some studies reported negative removal, i.e. addition of pollutants. This is caused by initial 313 wash out of pollutants from soil, which will fade during operation (Clary and Jones, 2016).

314 Negative removal efficiencies were therefore not considered in the calculation of median 315 removal efficiencies, but included in the uncertainty analysis.

316 We assumed that the top $20 \mathrm{~cm}$ of soil in green strips and swales has to be 317 renewed, and that sediment in the surface basin has to be removed every ten years due to 318 accumulation of pollutants (SI). However, the fate of polluted soil and sediment is unclear 319 as no treatment requirements are defined. Extensive treatment, such as thermal treatment 320 or washing, is only required for heavily polluted soils, for example stemming from industrial 321 or waste handling sites. We assumed landfilling or use in construction instead, which is a 322 practice commonly used for soil with limited metal contamination (McAdams and Shanight, 323 2014; Mulligan et al., 2001), and from which leaching was considered to be negligible. We 324 tested the sensitivity of this assumption by analysing a worst case scenario, where 325 removed soil and sediment is applied to natural soil, leaching to surface water by erosion. 326 The resulting ecotoxicity impacts were modelled using USEtox® characterisation factors 327 (Dong et al., 2014) for emissions of metals to natural soil. For nutrients, a conservative 328 leaching rate of $50 \%$ was used based on factors for agricultural soil published by Kirkeby 329 et al. (2013). 


\section{Results and discussion}

\subsection{Pollutant flow and discharges}

The fate of metals and nutrients depends on the flow path of stormwater and the 333 removal efficiencies of the single elements in each system (Figure 3). WWTPs (S1) 334 remove both metals $(70-90 \%)$ and nutrients $(84 \%)$ efficiently (Table 1$)$, largely through 335 accumulation in the sludge (Yoshida et al., 2015). 50\% of sludge is applied to agricultural 336 soil for fertilization in Denmark (Kirkeby et al., 2013). The remaining sludge is incinerated, 337 landfilled or mineralized and it is assumed that pollutants will not be released into the 338 environment during any of these processes.

None of the other elements is as efficient as the WWTP in removing pollutants. 340 Sedimentation in surface basins (S2) removes around half of the pollutants (Table 1). 341 Green strips implemented before soakaways and swales do not remove phosphorous, but 342 bind metals (35-57\% in green strips, and $46-65 \%$ in swales). Sand traps only show a very 343 limited potential to remove pollutants (0-22\%). Large fractions of metals (25-83\%) and 344 phosphorous (42\%) remain in the soil during infiltration both in soakaways (S3) and swales 345 (S4) (Table 1). All separate systems (S2-4) are designed for events with a five year return 346 period, and stormwater stemming from more severe events passes through the system 347 without removal and is discharged directly. This accounts for $3 \%$ of the total annual rain 348 volume (Sørup et al., 2016). 
349 Table 1. Median removal efficiencies of copper, zinc, and phosphorous by different stormwater infrastructure 350 elements. Minimum and maximum efficiencies are given in brackets. ${ }^{*}$ If the calculated median removal 351 efficiency was negative, no removal was assumed.

\begin{tabular}{|c|c|c|c|c|}
\hline \multirow[t]{2}{*}{ Element } & \multicolumn{3}{|c|}{ Median removal efficiency (minimum - maximum) } & \multirow[t]{2}{*}{ References } \\
\hline & Copper & Zinc & Phosphorous & \\
\hline WWTP & $90 \%$ & $70 \%$ & $84 \%$ & (Danish Nature Agency, 2014) \\
\hline Surface basin & $\begin{array}{c}46 \% \\
(1 \%-95 \%)\end{array}$ & $\begin{array}{c}65 \% \\
(1 \%-96 \%)\end{array}$ & $\begin{array}{c}52 \% \\
(12 \%-91 \%)\end{array}$ & $\begin{array}{l}\text { (Center for Watershed Protection, 2007; CIRIA, } \\
\text { 2015; Clary and Jones, 2016) }\end{array}$ \\
\hline Sand trap & $22 \%$ & $\begin{array}{c}0 \%{ }^{*} \\
(-23 \%-0 \%)\end{array}$ & $\begin{array}{c}0 \%^{*} \\
(-6 \%-0 \%)\end{array}$ & (Caltrans, 2003) \\
\hline Green strip & $\begin{array}{c}35 \% \\
(-6 \%-52 \%)\end{array}$ & $\begin{array}{c}57 \% \\
(52 \%-62 \%)\end{array}$ & $\begin{array}{c}0 \%{ }^{*} \\
(-100 \%-0 \%)\end{array}$ & $\begin{array}{l}\text { (Cederkvist et al., 2016; CIRIA, 2015; Clary and } \\
\text { Jones, 2016) }\end{array}$ \\
\hline Swales & $\begin{array}{c}46 \% \\
(1 \%-95 \%)\end{array}$ & $\begin{array}{c}65 \% \\
(1 \%-96 \%)\end{array}$ & $\begin{array}{c}0 \% * \\
(-100 \%-99 \%)\end{array}$ & $\begin{array}{l}\text { (Center for Watershed Protection, 2007; Clary and } \\
\text { Jones, 2016) }\end{array}$ \\
\hline $\begin{array}{l}\text { Infiltration } \\
\text { (soakaways / } \\
\text { swales) }\end{array}$ & $\begin{array}{c}25 \% \\
(2 \%-90 \%)\end{array}$ & $\begin{array}{c}83 \% \\
(33 \%-100 \%)\end{array}$ & $\begin{array}{c}42 \% \\
(-233 \%-88 \%)\end{array}$ & $\begin{array}{l}\text { (Cederkvist et al., 2015; Center for Watershed } \\
\text { Protection, 2007; Clary and Jones, 2016; Langeveld } \\
\text { et al., 2012; Rembout et al., 2007) }\end{array}$ \\
\hline
\end{tabular}




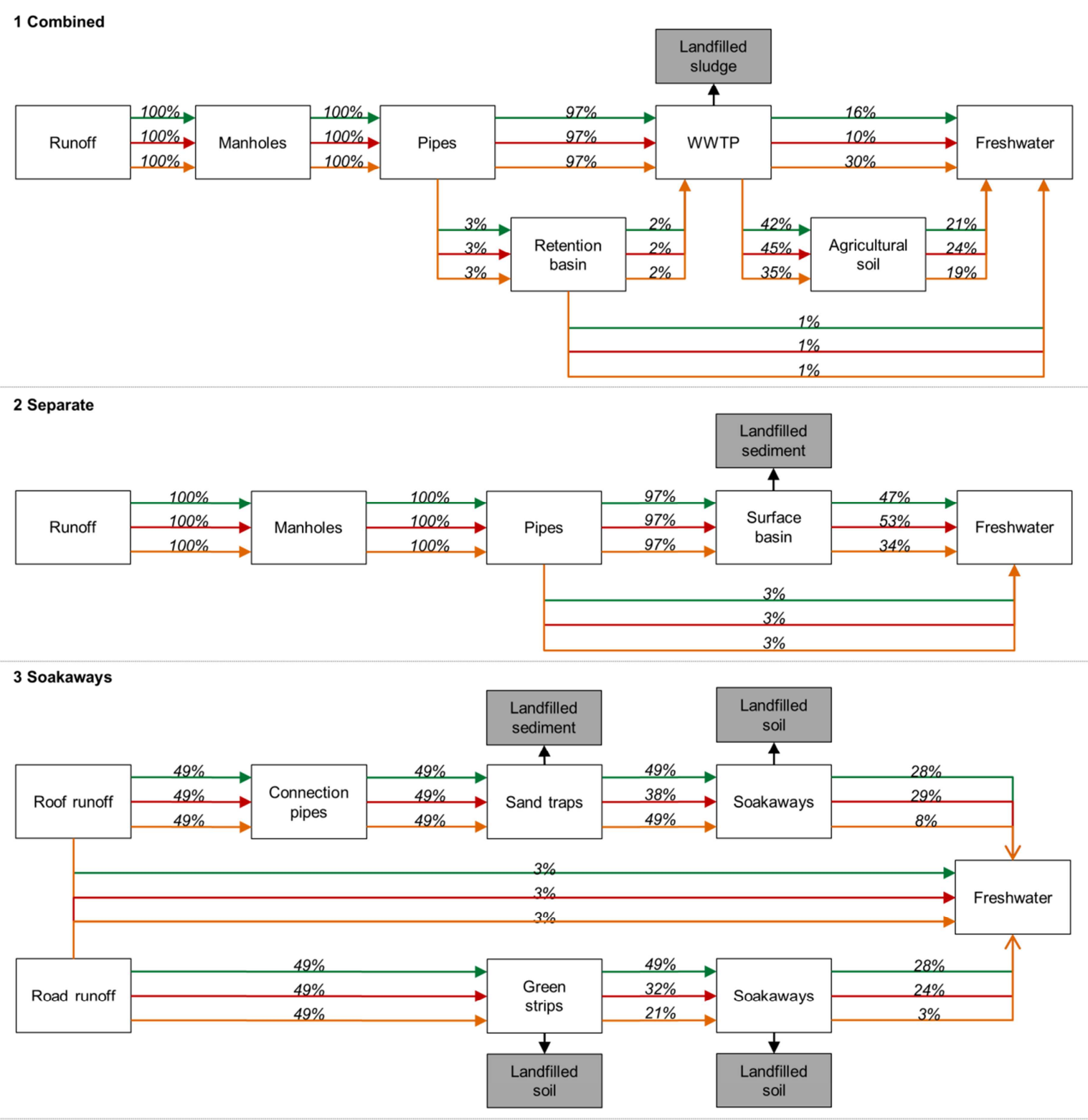

4 Swales

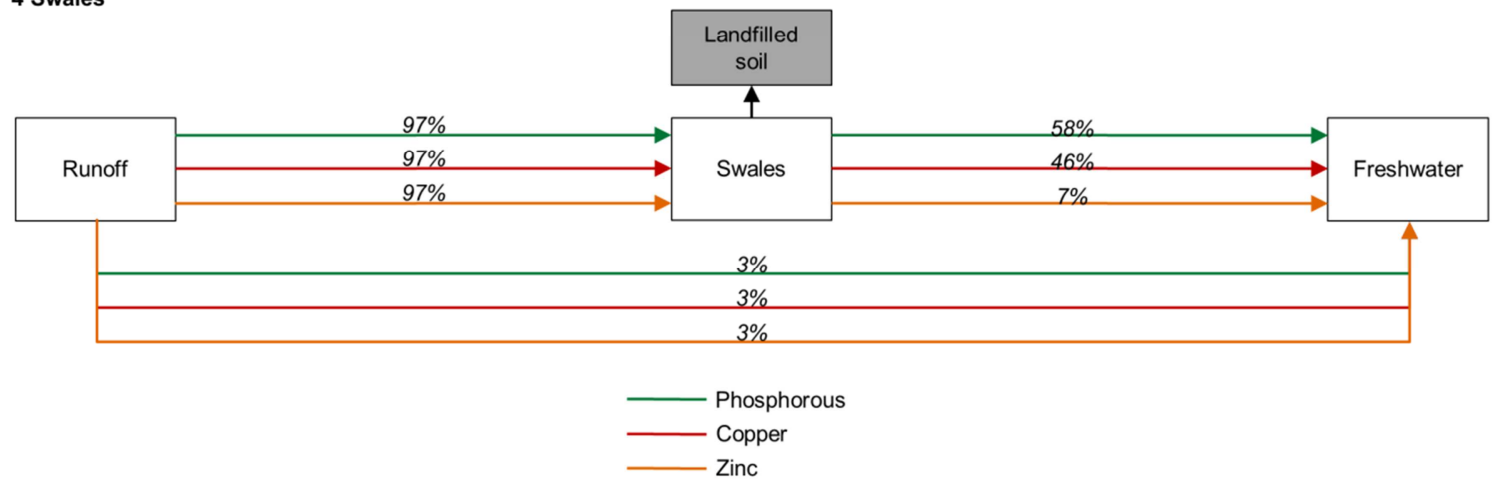

354 Figure 3. Pollutant flow in the four different systems, starting with $100 \%$ of the pollutant load in runoff (P: $3553.2 \mathrm{mg} / \mathrm{l}, \mathrm{Cu}: 59 \mu \mathrm{g} / \mathrm{l}, \mathrm{Zn}: 490 \mu \mathrm{g} / \mathrm{l}$ (Brudler et al., 2019)). The grey boxes mark pollutant "sinks", i.e. compartments in which it is assumed the pollutants are bound and disposed without leaching. 
358 The conclusions regarding the most (and least) sustainable systems differ when evaluating

359 infrastructure and point source emission impacts. The combined system (S1) has the 360 highest infrastructure impacts in all impact categories, with up to two times the impacts of 361 the separate system (S2). Concurrently, it has the lowest point source emission impacts. 362 Both green infrastructure systems have low infrastructure impacts, with swales (S4) having 363 the lowest infrastructure impacts in nine, and soakaways (S3) in four out of 13 364 infrastructure midpoint impact categories. However, with 54\% higher impacts than the 365 combined system, the green infrastructure systems have the highest freshwater 366 eutrophication impacts caused by point source emissions. The separate system (S2) has 367 the highest point source ecotoxicity impacts (4-50\% higher than the other systems). 368 Detailed values are listed in SI, and the maximum impact across all systems in each 369 category is shown in Figure 4.

370 This highlights that infrastructure and point source emission impacts have to be 371 evaluated in combination to assess the sustainability of SWM. If only infrastructure impacts 372 are included, the combined system (S1) is clearly the least sustainable option at midpoint 373 level. In contrast, only analysing point source emissions would lead to the conclusion that 374 it is the most sustainable system. 


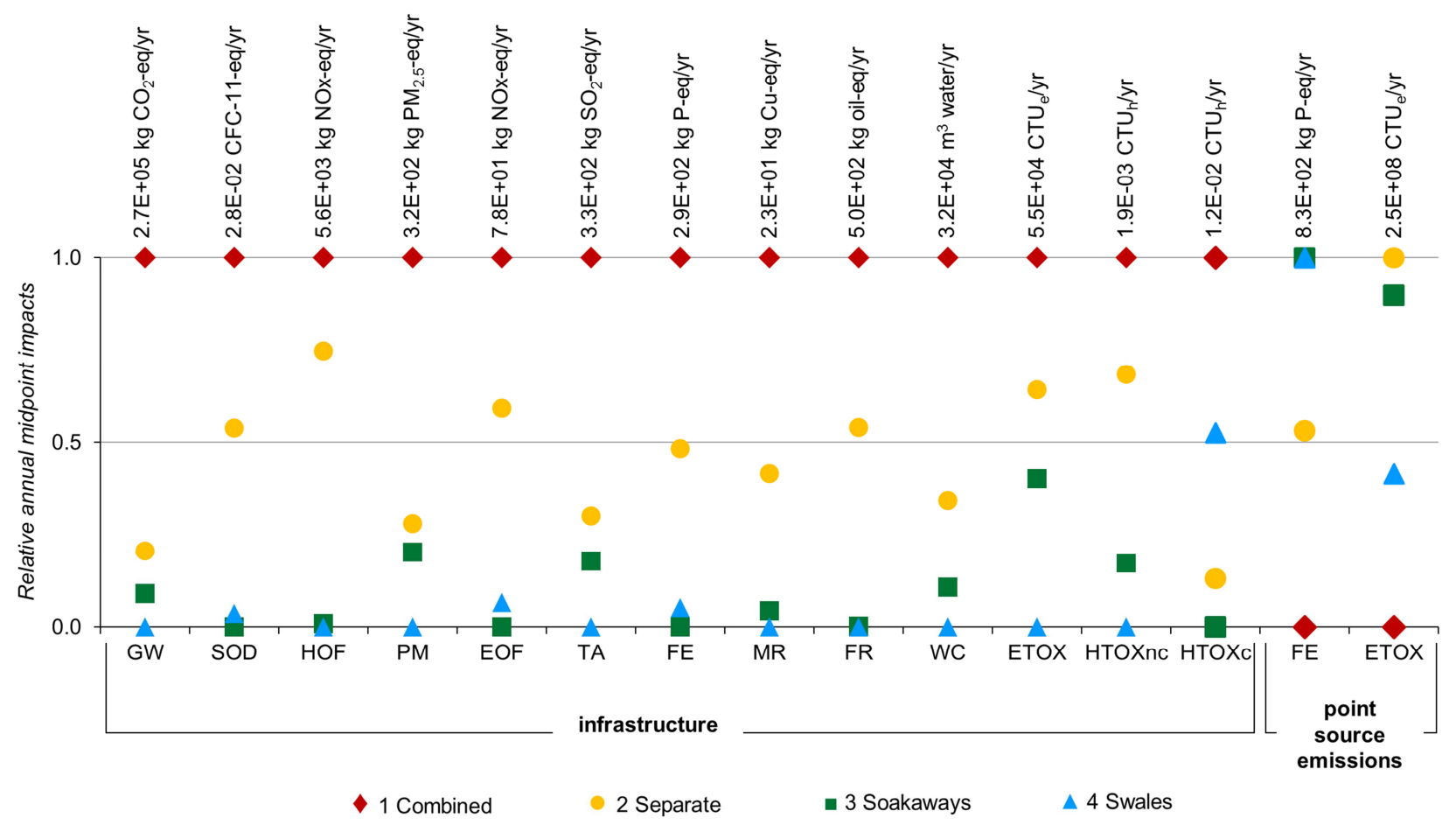

Figure 4. Annual infrastructure and point source emission impacts of the four different systems, normalized with reference to the highest (1) and lowest (0) impact in the single impact categories (GW = global warming, $\mathrm{SOD}=$ stratospheric ozone depletion, $\mathrm{IR}=$ ionizing radiation, $\mathrm{HOF}=$ human damage ozone formation, $\mathrm{PM}=$ particulate matter formation, EOF = ecosystem damage ozone formation, $T A=$ terrestrial acidification, $\mathrm{FE}=$ freshwater eutrophication, $M R=$ mineral resource availability, $F R=$ fossil resource availability, $W C=$ water consumption, ETOX = ecotoxicity, $\mathrm{HTOX}=$ human toxicity $(\mathrm{c}=$ cancer, $\mathrm{nc}=$ non-cancer $)$ ). Toxicity impacts are expressed in comparative toxic units (CTU).

\subsection{Environmental damage}

To compare the systems across impact categories and analyse point source emission and infrastructure impacts in combination, we calculated the resulting endpoint damage to three areas of protection: resource availability, ecosystems, and human health (Goedkoop et al., 2013). The damage to each area of protection is within the same order of magnitude across systems. The combined system (S1) causes most damage to resource availability and ecosystems, and second most to human health. In contrast to subsurface systems, Gl systems prevent damage to resource availability. Soakaways (S3) cause least damage to ecosystems and swales (S4) least damage to human health (Table 2). 
Table 2. Annual infrastructure and point source emission (in italic) damage to three areas of protection (resource availability, ecosystems, human health) caused by four different systems for managing stormwater according to Danish flood safety standards in a catchment area of $260 \mathrm{ha}$, over 25 years. Damage to human health and ecosystems caused by short-time exposure e.g. caused by flooding or overflows is not considered.

\begin{tabular}{|c|c|c|c|c|c|c|c|c|}
\hline & \multicolumn{2}{|c|}{1 Combined } & \multicolumn{2}{|c|}{2 Separate } & \multicolumn{2}{|c|}{3 Soakaways } & \multicolumn{2}{|c|}{4 Swales } \\
\hline & $\begin{array}{c}\text { Infra- } \\
\text { structure }\end{array}$ & $\begin{array}{c}\text { Point } \\
\text { source } \\
\text { emission }\end{array}$ & $\begin{array}{c}\text { Infra- } \\
\text { structure }\end{array}$ & $\begin{array}{c}\text { Point } \\
\text { source } \\
\text { emission }\end{array}$ & $\begin{array}{c}\text { Infra- } \\
\text { structure }\end{array}$ & $\begin{array}{c}\text { Point } \\
\text { source } \\
\text { emission }\end{array}$ & $\begin{array}{l}\text { Infra- } \\
\text { structure }\end{array}$ & $\begin{array}{c}\text { Point } \\
\text { source } \\
\text { emission }\end{array}$ \\
\hline \multicolumn{9}{|l|}{ Resource availability [USD/yr] } \\
\hline Mineral resource availability & $1.2 \mathrm{E}+02$ & & $7.1 \mathrm{E}+01$ & & $-8.7 \mathrm{E}+00$ & & $-9.0 \mathrm{E}+00$ & \\
\hline Fossil resource availability & 8.7E+03 & & $4.0 \mathrm{E}+03$ & & $-3.7 \mathrm{E}+03$ & & 03 & \\
\hline SUM & $8.8 \mathrm{E}+03$ & & $4.1 \mathrm{E}+03$ & & $-3.7 E+03$ & & $-5.2 E+03$ & \\
\hline \multicolumn{9}{|l|}{ Ecosystems [species.yr/yr] } \\
\hline \multicolumn{9}{|l|}{ Freshwater ecosystems } \\
\hline Global warming & 2.1E-08 & & $1.0 \mathrm{E}-08$ & & $6.5 \mathrm{E}-09$ & & 3.7E-09 & \\
\hline Eutrophication & $1.4 \mathrm{E}-05$ & $3.3 E-04$ & 7.7E-06 & $4.2 E-04$ & $-7.4 \mathrm{E}-07$ & $5.1 E-04$ & $-1.7 \mathrm{E}-06$ & $8.5 E-04$ \\
\hline Ecotoxicity & $6.0 \mathrm{E}-08$ & $1.8 E-04$ & $3.9 \mathrm{E}-08$ & 2.7E-04 & $2.2 \mathrm{E}-08$ & $2.6 E-04$ & $-6.0 \mathrm{E}-09-$ & $3.0 E-04$ \\
\hline Water consumption & $9.5 \mathrm{E}-10$ & & $6.5 \mathrm{E}-10$ & & $4.8 \mathrm{E}-11$ & & $5.8 \mathrm{E}-10$ & \\
\hline \multicolumn{9}{|l|}{ Terrestrial ecosystems } \\
\hline Global warming & 7.6E-04 & & 3.7E-04 & & 2.4E-04 & & $1.4 \mathrm{E}-04$ & \\
\hline Photochem. ozone form. & 4.3E-05 & & $2.5 \mathrm{E}-05$ & & $1.8 \mathrm{E}-05$ & & $9.1 \mathrm{E}-06$ & \\
\hline Acidification & $6.1 \mathrm{E}-05$ & & 3.5E-05 & & $-8.5 E-06$ & & $-3.9 \mathrm{E}-06$ & \\
\hline Water consumption & 2.1E-05 & & $1.5 \mathrm{E}-05$ & & 1.1E-06 & & 1.3E-05 & \\
\hline SUM & $9.0 \mathrm{E}-04$ & $5.1 E-04$ & $4.5 \mathrm{E}-04$ & $6.9 E-04$ & 2.5E-04 & $7.6 E-04$ & $1.5 \mathrm{E}-04$ & $1.2 E-03$ \\
\hline Human Health [DALY/yr] & 3.6E-01 & & 1.9E-01 & & 8.1E-02 & & 5.9E-02 & \\
\hline
\end{tabular}

(S1). Freshwater and terrestrial ecosystem damage contribute within the same order of magnitude to total ecosystem damage. Point source emissions cause the majority of 401 ecosystem damage in the separate systems $(60-88 \%)$ and $38 \%$ of the damage of the 402 combined system (Table 2). Across systems, point source emissions of nutrients causing 403 eutrophication impacts contribute almost twice as much to ecosystem damage as point 404 source emissions of metals causing ecotoxicity impacts.

If all stormwater would be discharged directly without treatment, 1.3E-03 
407 the total ecosystem damage caused is lower than this value, which implies that they are 408 effective in reducing ecosystem damage. This is in line with Clauson-Kaas et al. (2001) 409 and Byrne et al. (2017), who concluded that the avoided environmental impacts outweigh 410 the impacts of implementing and operating single SWM elements. However, this does not 411 apply to the combined system, which causes higher ecosystem damage than caused by 412 discharging stormwater without any SWM present.

Soakaways cause the lowest ecosystem damage, with point source emissions 414 contributing $75 \%$. This damage is calculated using characterisation factors for freshwater, 415 assuming that all pollutants in stormwater infiltrated to groundwater eventually reach 416 surface water. This is a worst case assumption as some pollutants would be retained in 417 the soil, i.e. removed by sorption and sequestration. Consequently, the ecosystem 418 damage of soakaways is probably even lower than the calculated results. However, 419 impacts on groundwater or the fate of pollutants discharged to groundwater are not 420 incorporated in existing LCIA methods, and would require the development of a new 421 impact pathway, which is outside of the scope of this paper.

Damage to resource availability, expressed as surplus cost, ranges between $4.1 \mathrm{E}+03(\mathrm{~S} 2)$ and $8.8 \mathrm{E}+03 \mathrm{USD} / \mathrm{yr}(\mathrm{S} 1)$ for the systems utilizing pipes. The difference in 424 damage can be partly explained by the difference in flood safety level, i.e. larger pipes, 425 and consequently more resources, are necessary for the combined system (S1) than for 426 the separate system (S2). The green infrastructure systems save resource costs, with 427 prevented damage ranging from $-3.7 \mathrm{E}+03(\mathrm{~S} 3)$ to $-5.2 \mathrm{E}+03 \mathrm{USD} / \mathrm{yr}(\mathrm{S} 4)$. Damage to fossil 428 resource availability is $2-3$ orders of magnitude higher than damage to mineral resource 429 availability across all systems (Table 2). 
According to the functional unit definition, the combined system is designed to 431 prevent flooding during events with a return period of ten years due to the increased risk to 432 humans from flooding with combined sewage. This results in higher resource demands for 433 larger pipes and basins than in separate systems, which are designed for events with a 434 return period of five years and consequently allow flooding from stormwater more often. 435 Flooding of infrastructure and buildings causes significant environmental damage due to 436 disposal and renovation processes (Hennequin et al., 2018; Petit-Boix et al., 2017). The 437 higher the flood safety level of the SWM system, the more economic and environmental 438 damage is prevented. Based on Hennequin et al. (2018), we calculated the environmental 439 damage to resource availability caused by the recovery from a $15 \mathrm{~cm}$ flooding of a single 440 house to 516 USD. A rain event with a return period of 10 years would be managed 441 without flooding in the combined system (S1) but would create flooding in the separate 442 systems (S2-4) and cause incremental environmental damage. If only nine (S2) to 27 (S4) 443 houses are flooded during such an event, the differences in resource availability damage 444 to the combined system (S1) are offset, effectively making the combined system the most 445 sustainable system for this area of protection. Detailed modelling of this damage is beyond 446 the scope of this paper, and would be too case dependent to be of generic interest. It 447 points, however, towards the fact that accounting for differences in flood safety levels by 448 including flood damage could substantially affect the conclusions of the comparative 449 assessment. This is aligned well with studies using economic assessments of cost of 450 infrastructure versus reduction of economic damage from flooding (Olsen et al., 2015; 451 Zhou et al., 2012).

The damage to human health ranges between 5.9E-02 (S4) and 3.6E-01 DALY/yr 453 (S1) (Table 2). The sustainability of the systems relative to each other and the contribution 
454 and uncertainty analysis of human health damage showed very similar patterns to 455 resource availability damage $(\mathrm{SI})$. We therefore only discuss damage to resource 456 availability in the following. The systems are furthermore designed to prevent flooding and 457 subsequent human contact with contaminated water, i.e. minimize human health damage 458 from contact with contaminated water. The WHO estimated that $3.7 \%$ of global DALYs are 459 attributable to water, sanitation, and hygiene (Prüss-Üstün et al., 2002), and the caused 460 damage is assumed to be negligible in comparison to the prevented damage.

a) Resource availability

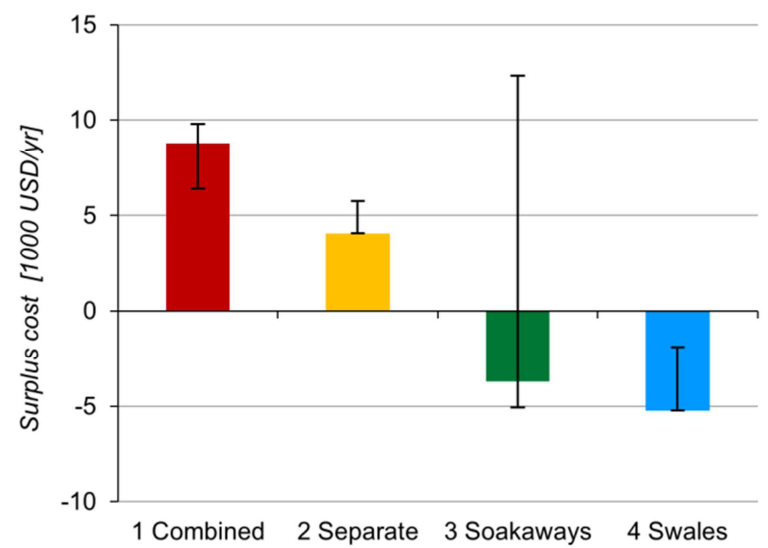

b) Ecosystems

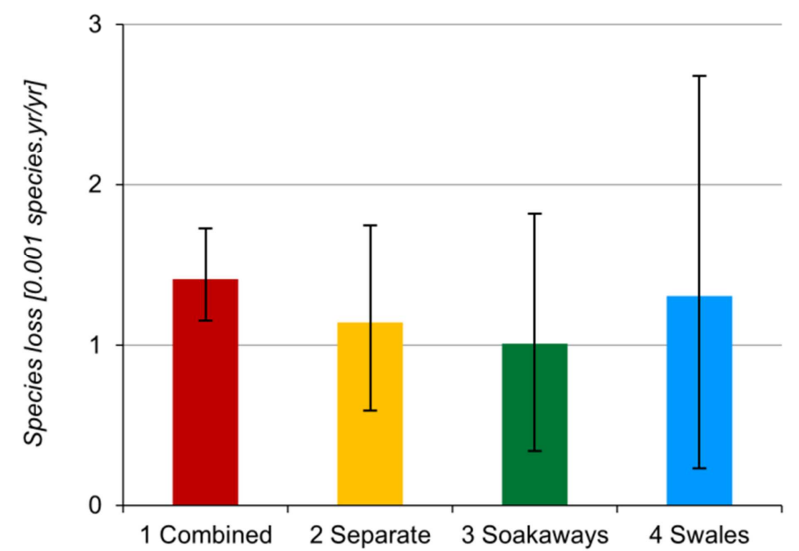

Figure 5. Damage to a) resource availability, b) ecosystems, caused by four different systems managing stormwater according to Danish flood safety standards in a catchment area of 260 ha, over 25 years. Negative values indicate prevented damage. Error bars illustrate the damage for a worst and best case for each system of all tested scenarios varying both infrastructure processes and point source emissions.

\subsubsection{Sensitivity of ecosystem damage}

The four systems show small differences in ecosystem damage that are hardly significant, considering the uncertainties that accompany the underlying modelling. The nominal ecosystem damage score is highest for the combined system (1.4E-03 species.yr/yr), and is mainly attributed to the operation stage with its discharges of polluted stormwater (36\%) and electricity consumption for WWT and pumping (19\%). The production of concrete, steel, plastic and gravel for pipes and basins causes significant damage (23\%), followed by filling and recycling of pipes at the end of life (18\%) (Figure 6). 
474 Overall, infrastructure processes contribute more (64\%) than point source emissions $475(36 \%)$ to total ecosystem damage, with discharges of untreated wastewater from overflows 476 contributing less than $1 \%$. The results are most sensitive to changes in the electricity 477 production: If electricity for WWT and pumping is produced only using wind power instead 478 of a Danish production mix, the damage is reduced by $18 \%$ (Figure 5). An increased 479 demand of electricity $(+25 \%)$ using a Danish production mix only leads to an increase in 480 total damage of $2 \%$.

a) Resource availability

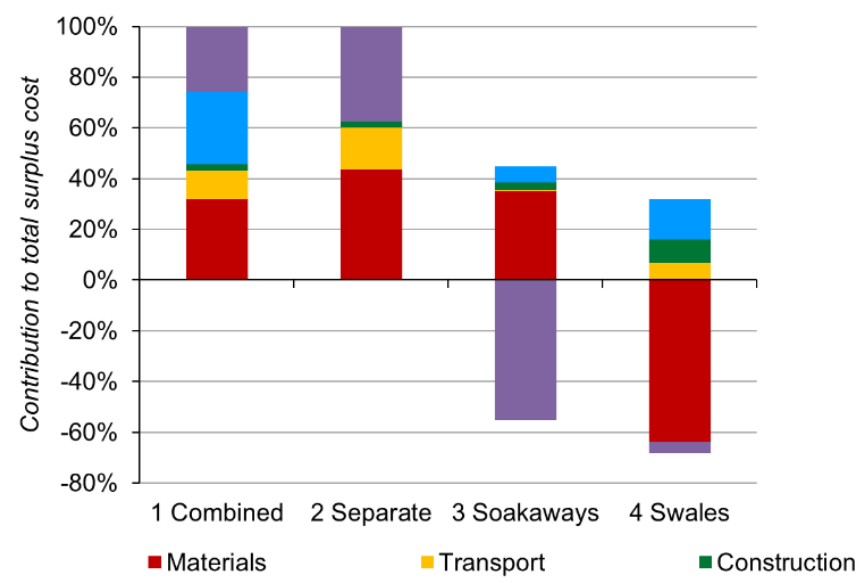

481 damage.

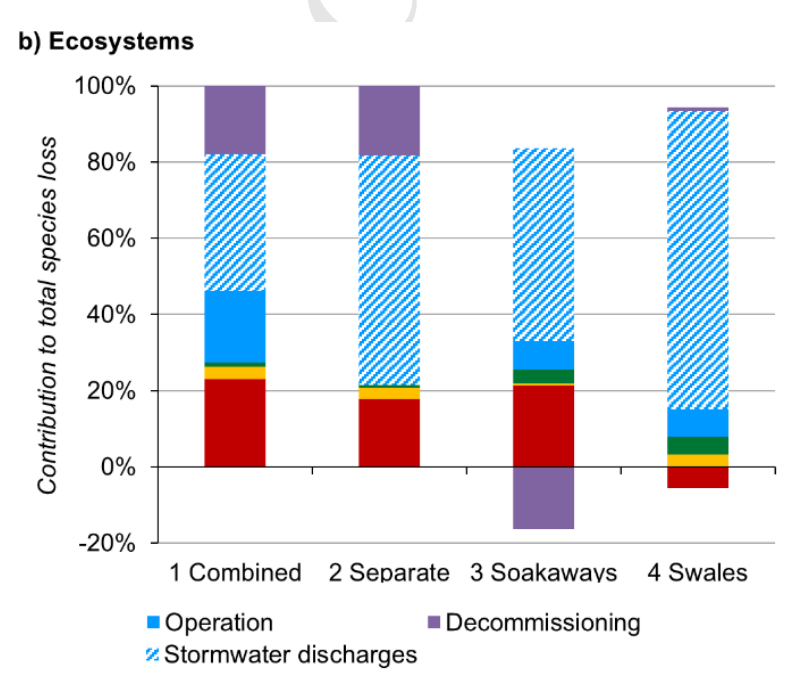

Figure 6. Relative contribution of life cycle stages (materials, transport, construction, operation with stormwater discharges, decommissioning) to a) the total resource availability damage, b) the total ecosystem

Removal of pollutants at the WWTP in the combined system (S1) is well documented and regulated (Danish Nature Agency, 2014), but data differentiating between wet and dry days is limited. The treatment efficiency depends on the quantity and quality of the influent, which differs between the combined and separate systems. We could not quantify these changes as no data was available. However, we tested the sensitivity of changes in the assumption regarding the fate of the sludge. We assume that $50 \%$ of the sludge is applied to agricultural soil, from where pollutants leach to freshwater, which 
causes $23 \%$ of the ecosystem damage of the combined system. However, this is a worst 493 case scenario, as Danish regulation specifies maximum concentrations of metals in sludge 494 that can be applied to agricultural soil (Ministry of Environment and Food DK, 2006). It is 495 difficult to evaluate how this affects the total mass of metals that ends up on agricultural 496 soil, as pre-treatment of sludge and metal content depend strongly on the treatment 497 facility. For treatment facilities in larger cities, sludge is not applied to soil at all, since the 498 transport to agricultural areas makes this economically unattractive. Consequently, the 499 damage from wastewater treatment could potentially be lower than in the base case. For 500 the separate systems, point source emissions account for the majority of ecosystem 501 damage (60-88\%) (Figure 6). Consequently, changes in the assumptions regarding the 502 fate of pollutants in stormwater affect the damage most. The removal efficiencies of 503 basins, filter soil and vegetation are highly uncertain, and measured values reported in 504 literature vary significantly (Table 1). Assuming maximum removal efficiencies decreases 505 the damage by 48 to $82 \%$, making separate systems less sustainable than the combined 506 system regarding ecosystem damage. In contrast, assuming minimum efficiencies 507 increases the damage between 53 and 105\% (Figure 5). Damage caused by swales is 508 most sensitive to these changes, making it either the most or least sustainable option 509 compared to all other systems.

Assuming $50 \%$ leaching from disposed soil and sediment, the damage is increased 511 only within the same order of magnitude and the conclusions regarding the systems with 512 highest and lowest damage do not change (SI). Consequently, ecosystem damage is less 513 sensitive to changes in leaching rates, than to changes in removal efficiency. soil. Flushing effects, e.g. of nutrients that are transformed from organic, sediment-bound 
516 form can lead to addition of pollutants (Winer, 2000). On the other hand, metals generally

517 sorb strongly to soils and a large fraction remains in the top layers of the soil (Johnson and

518 Hunt, 2016; Lemming et al., 2010; Turer et al., 2001). In surface basins, removal takes

519 place through sedimentation, which is significantly influenced by the basin design. For

520 example, implementing a forebay can remove up to $80 \%$ of particles and subsequently a

521 large fraction of metals (CIRIA, 2015). Similarly, elements like green strips can be

522 optimized to maximize removal before stormwater enters soakaways. Swales give the

523 opportunity to use designed filter media to maximize metal removal. This highlights the

524 possibility to significantly increase the sustainability of SWM systems: Low-tech elements

525 can be very efficient in removing pollutants and cause significantly less ecosystem

526 damage than combined systems, when designed accordingly. Additionally, regular

527 maintenance of all green infrastructure is necessary to ensure efficient removal over time 528 (CIRIA, 2015).

As an alternative to designing the systems to increase the removal efficiency of 530 pollutants, damage can also be limited at the source: Rain is only lightly polluted, and 531 takes up toxic compounds and nutrients from roofs and roads. If the sources of pollutants 532 in runoff are regulated, e.g. by restricting the use of metals in buildings and car parts, the 533 sustainability of SWM systems can be increased further (Ledin et al., 2004).

\subsubsection{Sensitivity of resource availability damage}

Damage to resource availability is only caused by infrastructure processes, and 536 within these mainly by material generation and decommissioning processes. The 537 contribution of transport and construction are minor in all systems. Operation consists of 538 removal of polluted sediment and soil and maintenance of green areas in separate 
539 systems, which contributes insignificantly to the total impacts (Figure 6). Only in the 540 combined system (S1), continuous electricity consumption for WWT and pumping during 541 the operation stage causes a major share of the damage (29\%) (Figure 6). The energy 542 consumption at the WWTP strongly depends on the treatment design, and the quantity 543 and quality of the influent. If electricity would be provided only by wind power, the total 544 damage to resource availability could be decreased by $27 \%$ (S1) (SI). 
The resource availability damage associated with pipes are higher in the combined

546 system (S1: $5.8 \mathrm{E}+03 \mathrm{USD} / \mathrm{yr}$ ) than in the separate system (S2: 4.0E+03 USD/yr) (SI).

547 Larger pipes are needed in the combined system, and the avoided damage of not 548 implementing a separate WW system (S1: -1.5E+02 USD/yr) does not offset this damage. 549 However, the relative importance of pipes is significantly higher in the separate system 550 (S2), where they account for $99 \%$ of the damage (S1: $66 \%$ ). This is because the separate 551 system doesn't require any continuous operation processes, and has very limited material 552 demands for the surface basin.

Plastic is used in significant amounts in all systems, for pipes with a diameter up to 554 400mm (S1-2), soakaways (S3) and geotextiles (S4). Soakaways and the connected 555 infrastructure of pipes and sand traps require most plastic $(1,265 \mathrm{t})$. Recycling of $1 \mathrm{~kg}$ of 556 plastic prevents resource availability damage of 0.39 USD, which is more than half of the 557 damage caused by the production of $1 \mathrm{~kg}$ of polypropylene and polyethylene (0.64 USD), 558 and equal to the damage caused by the production of $1 \mathrm{~kg}$ polyvinylchloride. These values 559 are characterized by some uncertainty, since the type of plastic could not be specified in 560 the recycling process used to model the impacts, and the resulting avoided impacts could 561 potentially be lower due to losses in the recycling process. Additionally, the disposal 562 process itself is uncertain, as technologies and legislation cannot be foreseen with 563 certainty. If we assume plastic is incinerated instead of recycled, resource availability 564 damage changes significantly in all separate scenarios $(+12 \%$ in $\mathrm{S} 1$ to $+432 \%$ in $\mathrm{S} 3)$, 565 making soakaways the least sustainable system (SI). Subsurface infrastructure has an 566 even longer expected life span (75 to 100 years), which makes the decommissioning 567 processes more unpredictable. We assume that excavation and recycling of concrete is 568 not economically feasible, especially for large structures like retention basins. If materials 
569 of subsurface solutions could be reused in the future, i.e. damage from material production 570 could be partly compensated for, the total damage from other life cycle phases would still 571 make subsurface systems less sustainable than Gl.

Where green infrastructure is implemented on existing road areas, it leads to 573 avoided material demands for road renewal, and avoided damage consequently. This 574 avoided damage negates the caused damage during other life cycle stages of swales (S4), 575 and in combination with benefits from plastic recycling also negates caused damage of 576 soakaways (S3). The size of the green strips implemented before soakaways 577 consequently has a large influence on the damage and assessing minimum and maximum 578 area requirements affects the damage significantly $(-77 \%$ to $+37 \%)(\mathrm{SI})$.

Grey infrastructure, i.e. pipes and retention basins, was assumed to have a longer 580 life time than green infrastructure. Halving the life time of green infrastructure elements 581 from 30 to 15 years reduces the avoided damage for swales by $45 \%$ (S4), and even leads 582 to induced, instead of avoided damage, for soakaways (SI). The lifetime is characterized 583 by a high uncertainty, since experience with green infrastructure is still limited. Continuous 584 maintenance, which is included in our assessment, can prolong the lifetime, and should 585 therefore be a priority when planning green infrastructure.

\subsection{Differentiation from risk assessment}

An impact assessment of point source emissions cannot replace a risk assessment

588 (RA), as is traditionally carried out when applying for discharge permits. A RA assesses worst case scenarios, i.e. analyses maximum peak discharges, and takes into account 590 local recipient characteristics. However, our assessment allows to compare the solutions 591 between each other, and to assess the long-term, accumulative effects. In the planning of 
592 stormwater systems, a life cycle impact assessment would realistically be supplemented

593 by a RA, and further assessments, e.g. regarding economic, recreational, and aesthetic 594 value of different systems.

\section{Conclusion}

596 Our study showed that the conclusions regarding the most, and least, sustainable system

597 for managing stormwater differ for infrastructure and point source emission impacts. A 598 combined sewer system causes the highest infrastructure impacts, and the lowest point 599 source emission impacts. Green infrastructure has significantly lower infrastructure 600 impacts due to limited material and operation demands, but current solutions remove less 601 stormwater pollutants and consequently cause higher point source emission impacts. Point 602 source emission impacts are significantly higher than infrastructure impacts at midpoint 603 level (ecotoxicity: four orders of magnitude, eutrophication: up to one order of magnitude).

604 The resulting endpoint damage to resource availability is highest for the combined system. 605 This is mainly caused by the production of materials like concrete and steel, 606 decommissioning processes of the pipe systems and continuous electricity consumption 607 for wastewater treatment and pumping. Higher flood safety levels are required for 608 combined than for separate systems due to higher health risks associated with flooding 609 with combined sewage. This requires more extensive infrastructure for combined system, 610 which partly explains the higher damage to resource availability. Green infrastructure 611 systems prevent damage to resource availability if roads are transformed to green areas, 612 and materials are recycled. 
613 Point source emissions contribute significantly to the total ecosystem damage of the

614 different systems (36 to $88 \%$ ), which highlights the importance of including stormwater

615 discharges in the assessment of SWM systems. The removal efficiency of low-tech

616 treatment elements like filter soil or surface basins is characterized by high uncertainty and

617 a potential increase in pollutant removal would make green infrastructure systems

618 significantly more sustainable than the combined system. The sustainability of green

619 infrastructure can further be optimized, e.g. through maximizing the life time with targeted 620 and continuous maintenance and recycling of materials.

\section{Acknowledgements}

622 The Innovation Fund Denmark Denmark and VCS Denmark, HOFOR and Aarhus Vand 623 funded the industrial $\mathrm{PhD}$ project in which this research was carried out.

\section{References}

625 Brudler, S., Arnbjerg-Nielsen, K., Hauschild, M.Z., Rygaard, M., 2016. Life cycle 626 assessment of stormwater management in the context of climate change adaptation. Water Res. 106, 394-404. doi:10.1016/j.watres.2016.10.024

628 Brudler, S., Rygaard, M., Arnbjerg-Nielsen, K., Hauschild, M.Z., Ammitsøe, C., Vezzaro, 629 L., 2019. Pollution levels of stormwater discharges and resulting environmental 630 impacts. Science of the Total Environment 663, 754-763.

631 Byrne, D.M., Grabowski, M.K., Benitez, A.C.B., Schmidt, A.R., Guest, J.S., 2017. 632 Evaluation of Life Cycle Assessment ( LCA ) for Roadway Drainage Systems. 
Caltrans, 2003. Caltrans Tahoe Highway Runoff Characterization and Sand Trap Effectiveness Studies. Sacramento, CA, US.

636 Cederkvist, Jensen, M.B., Ingvertsen, S.T., Bjerager, P., 2015. Notat om renseeffektivitet af filterjord - danske erfaringer. Byer i Vandbalance notat 6 .

638 Cederkvist, K., Jensen, M.B., Ingvertsen, S.T., Holm, P.E., 2016. Controlling stormwater quality with filter soil-event and dry weather testing. Water (Switzerland) 8, 1-18.

Center for Watershed Protection, 2007. National Pollutant Removal Performance 642 Database. Version 3.

643 CIRIA, 2015. The SuDS manual. doi:London C697

644 Clary, J., Jones, J., 2016. International Stormwater BMP Database - 2016 Summary 645 Statistics, Werf. doi:C-ITS Platform

646 Clauson-Kaas, J., Poulsen, T.S., Jacobsen, B.N., Guildal, T., Wenzel, H., 2001. 647 Environmental accounting - A decision support tool in WWTP operation and

Clavreul, J., Baumeister, H., Christensen, T.H., Damgaard, A., 2014. An environmental 650 assessment system for environmental technologies. Environ. Model. Softw. 60, 18-

Danish Nature Agency, 2014. Opdatering af nøgletal for miljøfarlige forurenende stoffer i spildevand fra renseanlæg. 
654

655

656

657

658

659

660

661

662

663

664

665

666

667

668

669

670

671

672

673

674

675

Dong, Y., Gandhi, N., Hauschild, M.Z., 2014. Development of Comparative Toxicity Potentials of 14 cationic metals in freshwater. Chemosphere 112, 26-33. doi:10.1016/j.chemosphere.2014.03.046

Göbel, P., Dierkes, C., Coldewey, W.G., 2007. Storm water runoff concentration matrix for urban areas. J. Contam. Hydrol. 91, 26-42.

Godskesen, B., Hauschild, M., Rygaard, M., Zambrano, K., Albrechtsen, H.J., 2013. Lifecycle and freshwater withdrawal impact assessment of water supply technologies. Water Res. 47, 2363-2374. doi:10.1016/j.watres.2013.02.005

Goedkoop, M., Heijungs, R., De Schryver, A., Struijs, J., van Zelm, R., 2013. ReCiPe 2008. A LCIA method which comprises harmonised category indicators at the midpoint and the endpoint level. Characterisation. A life cycle impact ... 133. doi:http://www.lcia-recipe.net

Gosset, A., Durrieu, C., Orias, E., Bayard, E., Perrodin, Y., 2017. Identification and assessment of ecotoxicological hazards attributable to pollutants in urban wet weather discharges. Environ. Sci. Process. Impacts 19, 1150-1168. doi:10.1039/c7em00159b

Hennequin, T., Sørup, H.J.D., Dong, Y., Arnbjerg-Nielsen, K., 2018. A framework for performing comparative LCA between repairing flooded houses and construction of dikes in non-stationary climate with changing risk of flooding. Sci. Total Environ. 642, 473-484.

Huijbregts, M., 1998. Application of uncertainty and variability in LCA. Int. J. Life Cycle Assess. 3, 273-280. doi:10.1007/BF02979835

Huijbregts, M.A.J., Steinmann, Z.J.N., Elshout, P.M.F., Stam, G., Verones, F., Vieira, 
676

677

678

679

680

681

682

683

684

685

686

687

688

689

690

691

692

693

694

695

696

697

M.D.M., Zijp, M., van Zelm, R., 2016. ReCiPe 2016: A harmonized life cycle impact assessment method at midpoint and enpoint level - Report 1: characterization. Natl. Inst. Public Heal. Environ. 194. doi:10.1007/s11367-016-1246-y

IDA Spildevandskomiteen, 2005. Funktionspraksis for afløbssystemer under regn. Skrift nr. 2766.

Ingvertsen, S.T., Jensen, M.B., Magid, J., 2011. A minimum data set of water quality parameters to assess and compare treatment efficiency of stormwater facilities. J. Environ. Qual. 40, 1488-1502. doi:10.2134/jeq2010.0420

ISO, 2006a. Environmental Management - Life Cycle Assessment - Requirements and guidelines - ISO 14044, ISO 14040:2006. Brussels, Belgium.

ISO, 2006b. Environmental Management - Life Cycle Assessment - Principles and framework - ISO 14044, ISO 14044:2006. Brussels, Belgium.

Johnson, J.P., Hunt, W.F., 2016. Evaluating the spatial distribution of pollutants and associated maintenance requirements in an 11 year-old bioretention cell in urban Charlotte, NC. J. Environ. Manage. 184, 363-370. doi:10.1016/j.jenvman.2016.10.009

Kirkeby, J., Rosenhagen, C., Høibye, L., Dalgaard, O.G., Neidel, T.L., Kromann, M., Hansen, J.P., Bruun, S., 2013. Livscyklusvurdering og samfundsøkonomisk analyse for anvendelse af spildevandsslam. Project no. 1459 [Life cycle assessment and socioeconomic analysis for the use of waste water sludge], Environmental Protection Agency, Copenhagen, Denmark. The Danish Environmental Protection Agency, Copenhagen, Denmark.

Langeveld, J.G., Liefting, H.J., Boogaard, F.C., 2012. Uncertainties of stormwater 
characteristics and removal rates of stormwater treatment facilities: Implications for stormwater handling. Water Res. 46, 6868-6880. doi:10.1016/j.watres.2012.06.001

700

Ledin, A., Auffarth, K.P.S., Boe-Hansen, R., Eriksson, E., Albrechtsen, H.-J., Baun, A., Mikkelsen, P.S., 2004. Use of runoff from roofs and impermeable areas (Brug af regnvand opsamlet fra tage og befæstede arealer).

Lemming, G., Hauschild, M.Z., Bjerg, P.L., 2010. Life cycle assessment of soil and groundwater remediation technologies: Literature review. Int. J. Life Cycle Assess. 15, 115-127. doi:10.1007/s11367-009-0129-x

Loubet, P., Roux, P., Loiseau, E., Bellon-Maurel, V., 2014. Life cycle assessments of urban water systems: A comparative analysis of selected peer-reviewed literature. Water Res. 67, 187-202. doi:10.1016/j.watres.2014.08.048

McAdams, T., Shanight, D.P.E., 2014. SURF Case Study \#009: Upper Tenmile Abandoned Mine Reclamation, Upper Tenmile Creek Mining Area NPL Site, Lewis and Clark County, Montana, USA.

Ministry of Environment and Food DK, 2006. Bekendtgørelse om anvendelse af affald til jordbrugsformål (Slambekendtgørelsen) 2017, 1-10.

Mulligan, C.N., Yong, R.N., Gibbs, B.F., 2001. Remediation technologies for metalcontaminated soils and groundwater: An evaluation. Eng. Geol. 60, 193-207. doi:10.1016/S0013-7952(00)00101-0

Nature Agency DK, 2011. Vandplan 2010-2015. Odense Fjord. Hovedvandopland 1.13 Vanddistrikt: Jylland og Fyn. 
719 Olsen, A., Zhou, Q., Linde, J., Arnbjerg-Nielsen, K., 2015. Comparing Methods of 720 Calculating Expected Annual Damage in Urban Pluvial Flood Risk Assessments. Water 7, 255-270. doi:10.3390/w7010255

722

723

724

725

726

727

728

729

730

731

732

733

734

735

736

737

738

739

740

Petit-Boix, A., Sevigné-ltoiz, E., Rojas-Gutierrez, L.A., Barbassa, A.P., Josa, A., Rieradevall, J., Gabarrell, X., 2017. Floods and consequential life cycle assessment: Integrating flood damage into the environmental assessment of stormwater Best Management Practices. J. Clean. Prod 162, 601-608. doi:10.1016/j.jclepro.2017.06.047

Pfister, S., Hellweg, S., 2009. The water "shoesize" vs. footprint of bioenergy. PNAS 106 (35), pp. E93-E94. doi:10.1073/pnas.0908069106

Prüss-Üstün, A., Kay, D., Fewtrell, L., Bartram, J., 2002. Unsafe water , sanitation and hygiene, in: Ezzati, M., Lopez, A., Roders, A. (Ed.), Comparative Quantification of Health Risks, Global and Regional Burden of Disease Attributable to Selected Major Risk Factors. World Health Organization, Geneva, Switzerland, pp. 1321-1352. doi:10.1002/9780470061619.ch32

Rembout, J., Boogaard, F.C., Kluck, J., Wentink, R., 2007. Zuiverende voorzieningen voor regenwater. Neersl. Tijdschr. voor Reg. Sect. van Ned. Ver. voor Waterbeheer NVA $13-18$.

Risch, E., Gasperi, J., Gromaire, M.C., Chebbo, G., Azimi, S., Rocher, V., Roux, P., Rosenbaum, R.K., Sinfort, C., 2018. Impacts from urban water systems on receiving waters - How to account for severe wet-weather events in LCA? Water Res. 128, 412-423. doi:10.1016/j.watres.2017.10.039 
741 Rosenbaum, R.K., Bachmann, T.M., Gold, L.S., Huijbregts, M.A.J., Jolliet, O., Juraske, R., Koehler, A., Larsen, H.F., MacLeod, M., Margni, M., McKone, T.E., Payet, J.,

Rosenbaum, R.K., Huijbregts, M.A.J., Henderson, A.D., Margni, M., McKone, T.E., Van De Meent, D., Hauschild, M.Z., Shaked, S., Li, D.S., Gold, L.S., Jolliet, O., 2011. USEtox human exposure and toxicity factors for comparative assessment of toxic emissions in life cycle analysis: Sensitivity to key chemical properties. Int. J. Life Cycle Assess. 16, 710-727. doi:10.1007/s11367-011-0316-4

Sørup, H.J.D., Lerer, S.M., Arnbjerg-Nielsen, K., Mikkelsen, P.S., Rygaard, M., 2016. Efficiency of stormwater control measures for combined sewer retrofitting under varying rain conditions: Quantifying the Three Points Approach (3PA). Environ. Sci. Policy 63, 19-26. doi:10.1016/j.envsci.2016.05.010

Spatari, S., Yu, Z., Montalto, F.A., 2011. Life cycle implications of urban green infrastructure. Environ. Pollut. 159, 2174-2179. doi:10.1016/j.envpol.2011.01.015

Taylor, S., Barrett, M., 2008. Assessing Environmental Impact of Storm Water Treatment Controls Through a Carbon Signature, in: 11th International Conference on Urban Drainage, Edinburgh, Scotland, UK, 2008.

The City of Copenhagen, 2011. Method catalogue for local rainwater drainage [WWW Document]. URL http://kk.sites.itera.dk/apps/kk_pub2/index.asp?mode=detalje\&id=1319

(accessed 
Turer, D., Maynard, J.B., Sansalone, J.J., 2001. Heavy metal contamination in soils of 766

United States Federal Law, 2002. Federal Water Pollution Control Act. Public Health Rep. 77, 107-13. doi:10.1111/j.1744-1714.1974.tb00320.x

Vollertsen, J., Hvitved-Jacobsen, T., Nielsen, A.H., 2012. Fact sheet for dimensioning surface basins (Faktablad om dimensionering af våde regnvandsbassiner).

Wang, R., Eckelman, M.J., Zimmerman, J.B., 2013. Consequential environmental and economic life cycle assessment of green and gray stormwater infrastructures for combined sewer systems. Environ. Sci. Technol. 47, 11189-11198. doi:10.1021/es4026547

Weidema, B.P., Bauer, C., Hischier, R., Mutel, C., Nemecek, T., Reinhard, J., Vadenbo, C.O., Wernet, G., 2013. The ecoinvent database: Overview and methodology, Data quality guideline for the ecoinvent database version 3 .

Wicke, D., Matzinger, A., Rouault, P., 2015. Relevance of organic substances in runoff in Berlin (Relevanz organischer Spurenstoffe im Regenwasserabfluss Berlins - OgRE).

Winer, R., 2000. National Pollutant Removal Performance Database for Stormwater Treatment Practices. Cent. Watershed Prot. Ellicott City, MD. 
785 Yoshida, H., Christensen, T.H., Guildal, T., Scheutz, C., 2015. A comprehensive 786 substance flow analysis of a municipal wastewater and sludge treatment plant. 787 Chemosphere 138, 874-882. doi:10.1016/j.chemosphere.2013.09.045

788 Zhou, Q., Halsnæs, K., Arnbjerg-Nielsen, K., 2012. Economic assessment of climate 789 adaptation options for urban drainage design in Odense, Denmark. Water Sci. 790 Technol. 66, 1812. doi:10.2166/wst.2012.386

791 Zhou, Q., Mikkelsen, P.S., Halsnæs, K., Arnbjerg-Nielsen, K., 2012. Framework for 792 economic pluvial flood risk assessment considering climate change effects and 793 adaptation benefits. J. Hydrol. 414-415, 539-549. doi:10.1016/j.jhydrol.2011.11.031 


\section{Life cycle assessment of point source emissions and infrastructure impacts of four types of urban stormwater systems}

Sarah Brudler, Karsten Arnbjerg-Nielsen, Michael Zwicky Hauschild, Christian Ammitsøe, Justine Hénonin, Martin Rygaard

\section{Highlights}

- Life cycle assessment of stormwater management at catchment scale

- Environmental impacts of four different stormwater systems are quantified

- All relevant impacts from point source emission and infrastructure are included

- Stormwater discharges cause significant impacts relative to the infrastructure

- Strategies to increase the sustainability of stormwater management are highlighted 